\title{
PRISONS MUST BE ABOLISHED
}

\author{
Alderf W. Lepmer
}

Most human societies are heavily steeped in tradition.* In North America tradition plays a very strong part in the concepts of law, order, and justice. Perhaps a good comparison is the earth centred cosmology of Thales and Ptolemy which was refuted by Johannes Kepler, Galileo, and Isaac Newton. Yet present day Astrologers make fantastic predictions, backed with complex calculations and elaborate charts, based on the antiquated concept of a geocentric universe. Like the astrologers, too many of those who dispense justice in Canada seem to cling to archaic thinking out of fear or superstition because they cannot rationally conceive of a society without its traditional barbarities. Since imprisonment can be (and frequently is) used as a political device of control and intimidation, the lawmakers are induced to adhere tenaciously to the inhumane and outmoded practices of incarcerating alleged criminals. That imprisoning a person convicted of a crime acts as a deterrent to others is unsubstantiated; that imprisonment rehabilitates the so-called criminal is highly contentious. If human society hopes to realize the ultimate potential of all its members, then prisons (which are an abhorrence to any civilized and enlightened society) must be abolished.

A large number of people feel quite strongly, how-

"Special credit to Claire Culhane, whose writing in Still Barred From Prison (1985) shows knowledge and insight concerning the problem of prison. 
ever, that prisons are necessary, that they protect society from the threat of dangerous criminals. Strong public feeling exists for the need to punish the person convicted of a crime. (It is not difficult to share this feeling when the atrocities committed by some are expounded and sensationalized by the news media.) Furthermore, the need for incarceration seems apparent when, upon release, the exconvict immediately returns to a life of crime or goes on a killing rampage apparently indicating uncontrollable psychotic behaviour. But the imprisonment of these unfortunate souls makes no more sense than locking up all people who have cancer or diabetes. Until recently the presence of a person with cancer caused considerable discomfort to others and many took pains to avoid such afflicted persons. Only a society that is itself sick will seek to punish the sick person, whether the illness is mental or organic in nature. "The insane criminal really can no more be considered a criminal than a child, since he/[she] is mentally in the same condition as an infant or animal" (Goldman 1969:114). Incarceration for this reason does not even serve the purpose of social vengeance.

That imprisonment does not work even for the occasional repeat offender is attested to by the alarming growth of the prison system and the prison population. Prisons do not rehabilitate: "Men treated like men react like men. Men treated like animals react like animals" (Martin 1953:275).

An important reason for the prison's inability to rehabilitate at least some prisoners is that a person trying to improve her/himself is confronted with constant lethargy and outright opposition within the unreality of the prison setting. Even education seems to be more condoned than encouraged. Conversely, clever ploys and outright intimidation are used to get prisoners involved in a multitude of silly social groups, just to keep everyone busy and to stifle the possibility of original thought. Furthermore, a fact that seems to elude judges and lawyers alike is that in many instances the accused has suffered such devastating personal losses by the time the case has come to trial, that any further punitive action like incarceration is a massive over- 
kill on the part of the courts. This creates such an aura of unreality for the prisoner that $\mathrm{s} / \mathrm{he}$ may indeed require some time to re-assess her/his life and try to make some sense out of it. For many this may never happen. "A nation that builds more prisons and imposes more repressive punishment, usually provokes more criminality" (Bianchi 1985:1). While it is possible that a few strong willed individuals, in spite of the system, may come out of the prison the better for it, the amount of self-discipline and selfmotivation required is too much for most.

Since prisons do not protect society or rehabilitate the criminal and cannot be proven to deter others, prisons must be abolished. They serve no useful purpose except for those employed within the prison system, the support industries which build and maintain the prison complex, and the legal establishment (which maintains a steady flow of people going into prison). That prisons help to protect society is wishful thinking because, by conservative estimates, at least twice as many criminals are at large as there are in prisons (Epp 1982:12). These are persons who have not been turned in or apprehended and probably never will be. Furthermore, the money saved by shutting down the prisons would go a long way toward enhancing many social programs; many problems that are presently dealt with under the criminal law could be handled with a great deal less impact on families if left to qualified social workers. 


\section{References}

Bianchi, H. "The Strategies of Abolition." Paper presented at the International Conference on Prison Abolition II, Amsterdam, June, 1985.

Culhane, C. (1985), Still Barred From Prison: Social Injustice in Canada. Black Rose Books.

Epp, E. (1982), Law Breaking and Peace Making. Argenta Friends Press.

Goldman, E. (1969), Anarchism and Other Essays. Dover Publications Inc.

Martin, J.B.(1953), Break Down The Walls. Ballantine Books. 